\title{
Institutional Structure of Sevastopol's Social Capital: Perception of Real Actors
}

\author{
Nataliia Simchenko \\ Institute of economics and management \\ V.I. Vernadsky Crimean Federal University \\ Simferopol, Russia \\ natalysimchenko@yandex.ru
}

\author{
Elena Piskun \\ Institute of Finance, Economics and Management \\ Sevastopol State University, Universitetskaya \\ Sevastopol, Russia \\ lenapiskun@mail.ru
}

\author{
Vladimir Khokhlov \\ Institute of Finance, Economics and Management \\ Sevastopol State University, Universitetskaya \\ Sevastopol, Russia \\ khokhlov_vv57@mail.ru
}

\begin{abstract}
The article is devoted to the study of the institutional structure of the social capital of the city of Sevastopol on the basis of assessing the perception by real actors of the level of satisfaction with life in the city. The relevance of the topic is due to the importance of forming an effective institutional structure of social capital in ensuring the implementation of social programs to improve the quality of life of the population. The study was carried out using the methods of system analysis, institutional approach, methods of economic comparative studies, structural-logical approach. In the course of the research, the following results were obtained: 1) in the structure of the city's social capital, such a component as "social networks and communications" is poorly developed at the subject level, which affects the deepening of information asymmetry processes in terms of the perception of social reforms by citizens; 2 ) the transformation of the structure of social capital of the city of Sevastopol should be based on the humanitarian and technological paradigm of the development of modern society.
\end{abstract}

Keywords: social capital, institutional structure, actors, social programs, Sevastopol

\section{INTRODUCTION}

\section{A. Materials}

The results of the author's research are based on the fundamental principles of the theory of social capital dating back to the works of P. Bourdieu, X. Briggs, J. Coleman, R. Goddard. Along with this, the study of the institutional structure of the social capital of Sevastopol through the prism of perception of real actors is carried out on the basis of the project of the Russian Foundation for Basic Research "Social capital and economic growth of Sevastopol: assessment and analysis models" (project No. 18-410-920001). In the course of the project, a number of articles were prepared, published in peer-reviewed scientific journals, the current numbers of which are included in international abstract databases and citation systems Web of Science, Scopus [1], [2], [3]

\section{B. Methodology}

The study of the institutional structure of Sevastopol's social capital through the prism of perception of real actors was carried out using the methods of economic comparative studies to assess the results of questioning and interviewing respondents, a structurally logical approach to identifying and structuring the prerequisites for the development of social capital of Sevastopol.

\section{Overview}

Discussion in the interpretation of the content of social capital reflects the diversity of views of modern researchers on its essence. In turn, this creates serious methodological difficulties when considering the issue of its measurement and evaluation by real actors. The aforementioned is evidence that it is very debatable to find a single generally accepted idea of the criteria and indicators with which you can measure the level of social capital. The authors of the theory of social capital, P. Bourdieu, J. Coleman, present theoretical and methodological foundations of the essence and forms of social capital as a social phenomenon [4], [5]. In our opinion, as economists, the application of the provisions of the theory of social capital to the study of the problems of socio-economic development of territories is very valuable [6], [7]. The work of X. Briggs, M. Mayer, C. Pierobon discusses the impact of forms of social capital on the economies of regions and cities 
TABLE 1. SOME ASSESSMENTS OF THE SOCIAL ASPECTS OF SEVASTOPOL BY VARIOUS SOCIO-PROFESSIONAL GROUPS

\begin{tabular}{|c|c|c|c|c|c|c|c|c|c|c|}
\hline & $\underset{\overparen{E}}{\ddot{E}}$ & $\stackrel{\grave{d}}{\grave{a}}$ & 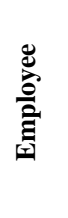 & 惫 & 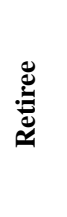 & 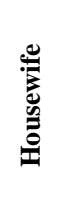 & 总 & 高 & 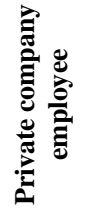 & : \\
\hline \multicolumn{11}{|c|}{ How long have you been living in Sevastopol? } \\
\hline Up to 3 years & 37.0 & 36.4 & 4.9 & 0.0 & 0.0 & 0.0 & 0.0 & 75.0 & 26.3 & 0.0 \\
\hline From 3-15 years & 30.4 & 36.4 & 12.2 & 0.0 & 16.7 & 0.0 & 0.0 & 0.0 & 18.4 & 50.0 \\
\hline From $16-25$ years & 6.5 & 9.1 & 4.9 & 40.0 & 0.0 & 0.0 & 100 & 0.0 & 21.1 & 12.5 \\
\hline More than 25 years & 0.0 & 9.1 & 31.7 & 0.0 & 66.7 & 0.0 & 0.0 & 0.0 & 18.4 & 25.0 \\
\hline From birth & 26.1 & 9.1 & 46.3 & 60.0 & 16.7 & 100 & 0.0 & 25.0 & 15.8 & 12.5 \\
\hline \multicolumn{11}{|c|}{ In your opinion. what is the standard of living of the population in Sevastopol today? } \\
\hline Very good & 0.0 & 9.1 & 0.0 & 20.0 & 0.0 & 0.0 & 0.0 & 0.0 & 23.7 & 8.3 \\
\hline Good & 6.5 & 9.1 & 0.0 & 20.0 & 0.0 & 0.0 & 0.0 & 0.0 & 23.7 & 8.3 \\
\hline Average & 67.4 & 45.5 & 68.3 & 80.0 & 83.3 & 100 & 0.0 & 25.0 & 15.8 & 41.7 \\
\hline Bad & 17.4 & 9.1 & 29.3 & 0.0 & 0.0 & 0.0 & 100 & 50.0 & 23.7 & 16.7 \\
\hline Very bad & 0.0 & 36.4 & 0.0 & 0.0 & 0.0 & 0.0 & 0.0 & 0.0 & 5.3 & 25.0 \\
\hline Difficult to answer & 8.7 & 0.0 & 2.4 & 0.0 & 16.7 & 0.0 & 0.0 & 25.0 & 15.8 & 0.0 \\
\hline \multicolumn{11}{|c|}{ Which of the following estimates most accurately describes the financial situation of your family? } \\
\hline $\begin{array}{l}\text { Not enough money even to } \\
\text { purchase food }\end{array}$ & 0.0 & 36.4 & 0.0 & 0.0 & 0.0 & 0.0 & 0.0 & 25.0 & 5.3 & 0.0 \\
\hline $\begin{array}{l}\text { Only enough money to buy } \\
\text { food }\end{array}$ & 13.0 & 9.1 & 17.1 & 0.0 & 33.3 & 0.0 & 100 & 0.0 & 31.6 & 0.0 \\
\hline $\begin{array}{l}\text { There is enough money to } \\
\text { purchase the necessary } \\
\text { products and clothing. larger } \\
\text { purchases have to be } \\
\text { postponed. }\end{array}$ & 52.2 & 36.4 & 61.0 & 80.0 & 16.7 & 100 & 0.0 & 50.0 & 23.7 & 62.5 \\
\hline $\begin{array}{l}\text { The purchase of most durable } \\
\text { goods is not difficult. but we } \\
\text { cannot buy an apartment }\end{array}$ & 21.7 & 9.1 & 19.5 & 20.0 & 50.0 & 0.0 & 0.0 & 25.0 & 13.2 & 25.0 \\
\hline $\begin{array}{l}\text { Enough money to not deny } \\
\text { yourself anything at all }\end{array}$ & 4.3 & 9.1 & 0.0 & 0.0 & 0.0 & 0.0 & 0.0 & 0.0 & 10.5 & 0.0 \\
\hline Difficult to answer & 8.7 & 0.0 & 2.4 & 0.0 & 0.0 & 0.0 & 0.0 & 0.0 & 15.8 & 12.5 \\
\hline \multicolumn{11}{|c|}{ In your opinion. how comfortable is it to live in Sevastopol? } \\
\hline Comfortable & 13.0 & 42.1 & 12.2 & 40.0 & 33.3 & 0.0 & 0.0 & 0.0 & 26.3 & 22.2 \\
\hline $\begin{array}{l}\text { Rather comfortable than } \\
\text { uncomfortable }\end{array}$ & 67.4 & 26.3 & 70.7 & 60.0 & 50.0 & 0.0 & 0.0 & 50.0 & 23.7 & 66.7 \\
\hline $\begin{array}{l}\text { More uncomfortable than } \\
\text { comfortable }\end{array}$ & 19.6 & 5.3 & 17.1 & 0.0 & 16.7 & 100 & 0.0 & 25.0 & 26.3 & 11.1 \\
\hline Uncomfortable & 0.0 & 26.3 & 0.0 & 0.0 & 0.0 & 0.0 & 100.0 & 25.0 & 23.7 & 0.0 \\
\hline \multicolumn{11}{|c|}{ How would you generally evaluate the socio-economic development of Sevastopol over the past 3 years? } \\
\hline Positively & 8.7 & 7.7 & 7.3 & 0.0 & 33.3 & 0.0 & 0.0 & 0.0 & 13.2 & 0.0 \\
\hline More positive than negative & 37.0 & 15.4 & 39.0 & 100.0 & 66.7 & 100 & 0.0 & 75.0 & 23.7 & 28.6 \\
\hline More negative than positive & 19.6 & 38.5 & 29.3 & 0.0 & 0.0 & 0.0 & 0.0 & 0.0 & 21.1 & 28.6 \\
\hline Negative & 2.2 & 15.4 & 9.8 & 0.0 & 0.0 & 0.0 & 100.0 & 0.0 & 13.2 & 14.3 \\
\hline Nothing changed & 10.9 & 0.0 & 2.4 & 0.0 & 0.0 & 0.0 & 0.0 & 0.0 & 21.1 & 14.3 \\
\hline Difficult to answer & 21.7 & 23.1 & 12.2 & 0.0 & 0.0 & 0.0 & 0.0 & 25.0 & 7.9 & 14.3 \\
\hline
\end{tabular}

[4]; [8], [9]. Along with this, a study by R. Goddard is interesting, which assessed the structure of factors of social capital that influence students' interest in knowledge of social sciences and the choice of a future profession in relation to their region of residence [10]

It should be noted that the multidimensionality of the studied category, which is multi-level and contains a rather extensive list of objects of analysis, creates not only interest in assessing social capital, but also difficulties in developing tools to obtain data that are accurate enough for interpretation and reliable results.

\section{REsults}

The use of quantitative methods for assessing social capital by scientists $\mathrm{S}$. Knack and $\mathrm{P}$. Keefer showed that the economic growth of countries depends on the level of trust, ethical standards, membership in associations [11]. As Russian scientists V. Ivanov and P. Pavlov note, "in countries with a higher level of confidence, economic activity is higher, measured by the share of investments in GDP, and higher than the rate of economic growth. In countries with high reserves of social capital, the state bureaucracy functions better. In other 
words, we can assume that social capital has on economic parameters: a) a direct impact through reducing the costs of collective actions and risky transactions (which are often the basis of the innovation process); b) indirect impact by reducing the costs of ensuring the accountability of the state, producing public goods and developing economic policy" [12].

In the course of a study of the institutional structure of Sevastopol's social capital on the basis of a questionnaire and interviewing of respondents - residents of the city, we obtained a number of results that require analysis and evaluation. The studies were conducted from September 2018 to January 2019. Citizens of Sevastopol of various social and professional groups and ages took part in the public poll. So, among the respondents, students and pupils made up $28.2 \%$, workers $-7.4 \%$, employees $-26.8 \%$, military and police officers - $3.4 \%$, pensioners - $4.0 \%$, housewives and the unemployed at $0,7 \%$, respectively, officials $-2.7 \%$, employees of private companies - $21.5 \%$, representatives of other occupations $-4.7 \%$. This percentage of respondents is understandable. At the beginning of 2019 according to official data from the Office of the Federal State Statistics Service for the Republic of Crimea 443,211 people lived in Sevastopol, of which about $18 \%$ are young people aged 15 to 25 years, the bulk of whom are studying in secondary specialized or higher educational institutions. The number of officials over the past five years has almost doubled from 3,581 people in 2013 to 6,779 in 2018.

The social characteristics of the region largely determine the dynamics of economic indicators. Table 1 presents the views of Sevastopol residents on certain social aspects of the city. All the data reflected in this article are collected and processed by the authors on the basis of a study of public opinion of the residents of Sevastopol and in fact represent the estimates and expectations of the region's population regarding social aspects and economic development.

According to the data presented in table 1, among the respondents from birth in Sevastopol there is a maximum number of military and police officers - 60\%, employees $46.3 \% ; 66.7 \%$ of pensioners are over 25 years old, $37 \%$ of students are up to 3 years old and $30.4 \%$ are from 3 to 15 years old, $36.4 \%$ of workers are up to 3 years old and $36.4 \%$ are from $3-\mathrm{x}$ up to 15 years.

According to respondents, almost all social and professional groups assess the standard of living in the region as average. Among students, 67.4\% answered this question in this way, among workers - $45.5 \%$, employees - $68.3 \%$, military and police officers - $80 \%$, pensioners - $83.3 \%$, housewives $-100 \%$. At the same time, officials who live in the city up to 3 years $(26.3 \%$ ) note a low standard of living - 50\%. The opinions of employees of private companies were divided into "very good", "good", "bad" at $23.7 \%$, respectively.

In a certain way, assessments of the standard of living and the material situation of the family correlate. So, the majority of students $(52.2 \%)$, workers $(36.4 \%)$, employees $(61 \%)$, military and police officers $(80 \%)$, housewives $(100 \%)$, officials $(50 \%)$, representatives of other social professional groups $(62.5 \%)$ noted that there was enough money to purchase the necessary products and clothing, and larger purchases had to be postponed. Unemployed (100\%) money is enough only for the purchase of necessary food products and $36.4 \%$ of workers do not have enough money even for these purposes.

Note that according to the census, $42 \%$ of Sevastopol residents aged 15 to 80 live on labor income. Pension as the main source of income was indicated by $25.5 \%$ of the population. Almost $27 \%$ of Sevastopol residents recognized themselves as dependents. At the same time, $57.3 \%$ or 224.5 thousand people of working age live in the city.

In general, respondents note that living in Sevastopol is more comfortable than uncomfortable: students - $67.4 \%$, employees - 70.7\%, military and police officers - $60 \%$, pensioners $-50 \%$, officials - 50\%, others $-66.7 \%$. Housewives $(100 \%)$ are more likely to live uncomfortably than comfortably; unemployed are uncomfortable (100\%). Estimates of employees of private companies vary from comfortable $-26.3 \%$, to uncomfortable $-23.7 \%$. Most workers are generally happy with everything $-68.4 \%$.

The social and economic development of Sevastopol over the past 3 years was rather positive than negatively evaluated: students - $37 \%$, employees - 39\%, military and police officers - $100 \%$, pensioners - $66.7 \%$, officials - $75 \%$, Housewives $100 \%$. As in previous estimates, employees of private companies have different perceptions of changes in this issue from "positive" - $13.2 \%$, to "nothing has changed" $-21.1 \%$.

Consider the results of the study in terms of satisfaction with the quality of life and the level of implementation of social programs for the population in various age groups. 
TABLE 2. DISTRIBUTION OF ANSWERS OF RESPONDENTS OF VARIOUS AGE GROUPS REGARDING THE ASSESSMENT OF THE POSITION “WHAT FEELINGS DO YOU HAVE FOR SEVASTOPOL?” (\%)

\begin{tabular}{|c|c|c|c|c|c|c|}
\hline \multirow{2}{*}{$\begin{array}{c}\text { Age category } \\
\text { years }\end{array}$} & \multicolumn{6}{|c|}{ Qualitative Grades } \\
\hline & $\begin{array}{l}\text { A high degree of } \\
\text { satisfaction with } \\
\text { life in Sevastopol }\end{array}$ & $\begin{array}{l}\text { The average degree of } \\
\text { satisfaction with life in } \\
\text { Sevastopol }\end{array}$ & $\begin{array}{c}\text { The position of } \\
\text { indifference to what is } \\
\text { happening in Sevastopol }\end{array}$ & $\begin{array}{l}\text { Intention to go to } \\
\text { another city of the } \\
\text { Republic of Crimea }\end{array}$ & $\begin{array}{l}\text { Intention to go } \\
\text { to another city } \\
\quad \text { in Russia }\end{array}$ & $\begin{array}{c}\text { Intention to } \\
\text { leave } \\
\text { Russia }\end{array}$ \\
\hline $15-24$ & 15.7 & 29.9 & 12.3 & 5.3 & 19.3 & 17.5 \\
\hline $25-34$ & 25.0 & 50.0 & 0 & 4.2 & 4.1 & 16.7 \\
\hline $35-44$ & 62.9 & 29.7 & 0 & 0 & 0 & 7.4 \\
\hline $45-54$ & 52.9 & 35.3 & 0 & 0 & 0 & 11.8 \\
\hline $55-64$ & 41.2 & 41.2 & 5.8 & 0 & 5.9 & 5.9 \\
\hline 64 and older & 58.8 & 29.4 & 11.8 & 0 & 0 & 0 \\
\hline
\end{tabular}

Table 2 shows the results of the distribution of respondents' answers regarding the assessment of the position "What feelings do you have for Sevastopol?".

It should be noted that more than $29.0 \%$ of respondents aged 15-24 reported that they were generally satisfied with their life in Sevastopol. At the same time, $17.5 \%$ of respondents of the same age category would like to leave Russia altogether (this is the highest negative indicator among all available age groups). $62.9 \%$ of respondents in the 35-44 age category emphasized that they were happy to live in the hero city of Sevastopol. The results obtained indicate the need for much more attention from the leadership of federal significance of Sevastopol to the problems of semantic employment of youth.

Below are the results of a survey of residents of Sevastopol regarding the degree of satisfaction with the implementation of social programs for the population in Sevastopol (Table 3).

The results of the analysis of the respondents' answers regarding the assessment of the level of satisfaction with the implementation of social programs in Sevastopol suggest that in general the level of implementation of social programs for the population remains low. The highest percentage of negative responses, characterized by elementary ignorance of citizens about the existence of such programs, is observed among young citizens of the economically active population of Sevastopol aged 25-34. Moreover, 47.4\% of youth aged 1524 are also unaware of the existence of such programs. The data obtained allow us to testify that such an important component of social capital as "social networks and communications" is developed rather poorly at the subject level.

The data presented indicate a gradual decrease in the indicator characterizing the level of trust in society, crowding out trust and its replacement, and this greatly complicates the use of social capital for the benefit of the economy and society as a whole.

The results of the perception of real actors in the institutional structure of the social capital of Sevastopol characterize, first of all, the socio-economic attitude of actors to the most important components of social capital and the development of society. Most respondents noted the importance of developing social contacts between the state authorities of the subject and citizens of the city. Moreover, ensuring the semantic employment of youth is a priority for the development of the city's social capital in ensuring the activation of small and medium-sized enterprises in Sevastopol.

Ensuring the development of social capital in the direction of improving management relations between the authorities of Sevastopol at the subject level and the residents of the city determines the importance of the development of social networks. In this regard, a very relevant direction in ensuring the development of Sevastopol as a "Smart city" is the development of IT infrastructure as a factor in the cohesion of social networks of residents and visitors of the city.

In modern literature, the development of the Smart city concept is based on the idea of open / ajar innovations that can ensure the development of IT infrastructure in the future [14]. Based on the analysis of the current IT landscape of the city and a number of ongoing projects / programs for the

TABLE 3. DISTRIBUTION OF ANSWERS OF RESPONDENTS OF VARIOUS AGE GROUPS REGARDING THE ASSESSMENT OF THE LEVEL OF SATISFACTION WITH THE IMPLEMENTATION OF SOCIAL PROGRAMS FOR THE POPULATION IN SEVASTOPOL (\%)

\begin{tabular}{|c|c|c|c|c|c|}
\hline \multirow[t]{2}{*}{ Age category years } & \multicolumn{5}{|c|}{ Qualitative Grades } \\
\hline & Satisfied & $\begin{array}{c}\text { Rather yes than } \\
\text { no }\end{array}$ & $\begin{array}{c}\text { More likely no } \\
\text { than yes }\end{array}$ & Not satisfied & $\begin{array}{c}\text { I do not know about the existence } \\
\text { of social programs for the } \\
\text { population }\end{array}$ \\
\hline $15-24$ & 3.5 & 14.1 & 12.3 & 22.7 & 47.4 \\
\hline $25-34$ & 0 & 8.3 & 16.7 & 8.3 & 66.7 \\
\hline $35-44$ & 0 & 22.3 & 14.8 & 29.6 & 33.3 \\
\hline $45-54$ & 0 & 11.8 & 58.8 & 23.5 & 5.9 \\
\hline $55-64$ & 0 & 11.8 & 23.5 & 5.9 & 58.8 \\
\hline 64 and older & 5.9 & 70.5 & 5.9 & 5.9 & 11.8 \\
\hline
\end{tabular}


population, the role of sharing information resources in a sharing economy should be emphasized. The effective sharing of publicly available resources in order to create an urban and regional ecosystem makes it important to establish sustainable partnerships and develop strategies for the interaction of key actors.

Note that the city is regarded as the "smart" category if investments in human capital, social capital, traditional transport and modern communication infrastructure ensure sustainable economic growth and a high level of quality of life [13]; [14]. At the same time, it is necessary to ensure effective public-private partnerships and the rational use of resources [15].

Social capital, as an intangible resource, provides the exchange of knowledge between the actors of a virtual network community. Moreover, the development dynamics of such a network community is positive if the social capital of the participants is reproduced. Otherwise, a decrease in the value of the social capital of participants leads to leveling the role and significance of such networks. In this regard, within the framework of the institutional structure of the social capital of Sevastopol, it is advisable to emphasize the role of the social Internet of things [13]. According to modern researchers, an analysis of the development of the social Internet of things will help explain the decisions of actors regarding their actions as participants in various sets of social networks in terms of deciding on the development of relationships in the network or, conversely, their closure [17].

The key advantages of the development of the social Internet of things, compared to the Internet of things (IoT), are the following: leveling scalability; increased actor confidence; Identifying additional co-consumption resources to maximize value and productivity [18], [19]. as the scientists of D. Ursino and L. Virgili rightly note, in recent years the development of the Internet of things has been increasingly accompanied by the need to analyze social networks involved in information and communication channels, which makes it necessary to talk about the humanization of the Internet of things [20].

The foregoing determines the importance of further research on the transformation of the structure of social capital of Sevastopol based on the interpretation and justification of the dominance of the humanitarian and technological paradigm of the development of modern society.

\section{CONCLUSION}

Transposing the components of the triad of social capital: social networks, trust and norms - to the level of the city of federal significance of Sevastopol, we note that the processes of ensuring a high civic culture of the city should be interdependent, i.e. those that would have a bilateral permanent connection.

In the course of the study of the institutional structure of the social capital of the city of Sevastopol on the basis of a questionnaire survey and interviewing of respondents residents of the city, a number of results were obtained that underlie the analysis of the perception by real actors of the most important factors of social capital - social networks and the social environment. Almost all socio-professional groups assess the standard of living in the region as average. The socio-economic development of the city of Sevastopol over the past 3 years is assessed by respondents as positive rather than negative. More than $29 \%$ of respondents aged 15-24 reported that they were generally satisfied with their life in Sevastopol; $62.9 \%$ of respondents in the $35-44$ age category emphasized that they were happy to live in the hero city of Sevastopol. At the same time, $47.4 \%$ of youth aged 15-24 do not know about the existence of social programs for the population that are implemented in the city. The data obtained indicate that such an important component of social capital as "social networks and communications" is developed rather poorly at the subject level. The development of the social capital of Sevastopol in ensuring the economic growth of the city should be based, first of all, on a stable institutional base, where transparency of compliance and rule of law by all participants in the development of civil society is crucial.

The studies conducted allowed us to conclude that the most important prerequisites for the development of the social capital of the city of Sevastopol are: the historically inherent spirit of patriotism for educating the young generation on the basis of history, traditions, preserving world-class cultural and historical complexes and developing a modern center for the Black Sea Fleet of the Russian Navy; high quality of human capital; high level of self-organization of citizens; favorable sociocultural environment for the training of new generations of highly qualified specialists. The implementation of the strategic objectives of the development of the city of Sevastopol should be based, first of all, on a stable institutional base, where transparency of compliance and rule of law by all participants in the development of civil society is crucial.

\section{ACKNOWLEDGMENTS}

The reported study was funded by RFBR and Government of the Sevastopol according to the research project № 18-410920001.

\section{REFERENCES}

[1] E. I. Piskun and V. V. Khokhlov, "Economic development of the Russian Federation's regions: factor-cluster analysis", Ekonomika regiona [Economy of region], 2019, 15 (2), pp. 363-376.

[2] N. Simchenko and E.Piskun, "Contribution of corporate social responsibility and social capital management into quality of life: models of evaluation", International Journal for Quality Research, 2019, 13 (3), pp. 689-704.

[3] E. Piskun, V. Khokhlov, and N. Simchenko, "Economic development of Sevastopol and its influence on the population's life quality", International Journal for Quality Research, 2019, 13 (2), pp. 485-500.

[4] P. Bourdieu, "The Forms of Capital", Handbook of Theory and Research for the Sociology of Education, New York, Greenwood, 1986.

[5] X. Briggs and S. De, "Social capital and the cities: advice to change agents", National Civic Review, 1997, vol. 86, pp. 111-117.

[6] J. Coleman, "Social Capital in the Creation of Human Capital", American Journal of Sociology, Supplement: Organizations and Institutions: Sociological and Economic Approaches to the Analysis of Social Structure, 1988, vol. 94, pp. 95-120. 
Frameworks for Open Innovation", The Future Internet, 2011, pp. 431446.

[15] M. Batty, K. W. Axhausen, F. Giannotti, A. Pozdnoukhov, A. Bazzani, M. Wachowicz, G. Ouzounis, and Y. Portugali, "Smart cities of the future", European Physical Journal: Special Topics, 2012, 214 (1), pp. 481-518.

[16] F. Herraiz Faixó, F.-J. Arroyo-Cañada, M. P. López-Jurado, and A. M. Lauroba Pérez, "Digital assets Horizon in smart cities: Urban congestion management by IoT, Blockchain/DLT and human reinforcement", Advances in Intelligent Systems and Computing, 2020, vol. 894, pp. 63-82.

[17] A. Razzaque and A. Hamdan, "Peak-End Rule Promotes Social Capital for Knowledge Management in Thru Social Internet of Things (Book Chapter)", Studies in Computational Intelligence, 2020, vol. 846, pp. 235-247.

[18] K. H. Rahouma, R. H. M. Aly, and H. F. Hamed, "Challenges and Solutions of Using the Social Internet of Things in Healthcare and Medical Solutions - A Survey", Studies in Computational Intelligence, 2020, vol. 846, pp. 13-30.

[19] H. Vahdat-Nejad, Z. Mazhar-Farimani, and A. Tavakolifar, "Social Internet of Things and New Generation Computing - A Survey", Studies in Computational Intelligence, 2020, vol. 846, pp. 139-149.

[20] D. Ursino and L. Virgili, "Humanizing IoT: Defining the Profile and the Reliability of a Thing in a Multi-IoT Scenario", Studies in Computational Intelligence, 2020, vol. 846, pp. 51-76.

[14] H. Schaffers, N. Komninos, M. Pallot, B. Trousse, M. Nilsson, and A. Oliveira, "Smart Cities and the Future Internet: Towards Cooperation 